\title{
IMPACT OF STONE SIZE, LOCATION, AND STONE COMPOSITION ON THE EFFICACY OF EXTRACORPOREAL SHOCK WAVE LITHOTRIPSY FOR RESIDUAL STONE AFTER PERCUTANEOUS NEPHROLITHOTOMY
}

\author{
Zuhri Sawal, Doddy M Soebadi \\ Department of Urology, Faculty of Medicine, Universitas Airlangga, Dr. Soetomo General Hospital, Surabaya, \\ Indonesia
}

\section{ABSTRACT}

This study aimed to determine the impact of stone size, location and stone composition the efficacy of extracorporeal shock wave lithotripsy (ESWL) in the management of residual stone after percutaneous nephrolithotomy (PCNL). The design of this study was a retrospective that conducted between January 2012 until December 2016. The population in this study were all patients with residual stones post PCNL. Exclusion criteria were patients with multiple stones and patients with a history of previous treatment for residual stones such as nephroscopy, flexible ureterorenoscopy, ESWL or medical therapy). The variables studied in this study were stone size, stone location, and stone composition. Before ESWL was carried out, all patients underwent Kidney Ureter Bladder (KUB). After ESWL, all patients underwent ultrasonography (USG) and KUB to determine the stone clearance status. The sample of this study was 125 patients. The overall stone-free rate (SFR) of ESWL in managing post-PCNL residual stones is $72 \%$. SFR based on stone size variable are $73.7 \%$ and $71.3 \%$ respectively for stones with a size = $5 \mathrm{~mm}$ and $>5 \mathrm{~mm}(\mathrm{p}=0.78)$. SFR based on stone location variable was $67.1 \%, 75.8 \%$, and $81.8 \%$ respectively for the residual stone located at the upper pole, middle pole and lower pole. There are no significant differences in the entire variable. This study concludes that ESWL can be used as effective additional management to treat post-PCNL residual stones with satisfactory SFR.

Keywords: Residual stone; percutaneous nephrolithotomy; extracorporeal shock wave lithotripsy

\section{ABSTRAK}

Tujuan dari penelitian ini adalah untuk mengetahui pengaruh ukuran batu, lokasi dan komposisi batu terhadap efikasi dari extracorporeal shock wave lithotripsy (ESWL) dalam tatalaksana batu residual pasca operasi percutaneous nephrolithotomy $(P C N L)$. Desain studi ini adalah retrospektif yang dilakukan pada periode bulan Januari 2012 hingga Desember 2016. Populasi pada studi ini adalah semua pasien dengan batu residual pasca operasi PCNL. Kriteria ekskulsi pada studi ini adalah pasien dengan batu multiple dan pasien dengan riwayat pernah mendapatkan tatalaksana batu residual lainnya (nefroskopi, fleksibel ureterorenoskopi, terapi medikamentosa atau ESWL). Variabel yang diteliti pada studi ini adalah ukuran batu, lokasi batu, dan komposisi batu. Sebelum dilakukan ESWL, semua pasien dilakukan pemeriksaan radiologi Kidney Ureter Bladder (KUB). Setelah ESWL, dilakukan pemeriksaan ultrasonography (USG) dan KUB untuk mengetahui status batu tersebut. Sampel dari penelitian ini sejumlah 125. Keseluruhan stone free rate (SFR) ESWL pada batu residual pasca PNCL adalah sebesar 72\%. SFR berdasarkan variable ukuran batu adalah 73,7\% dan 71,3\% masing-masing untuk batu dengan ukuran = $5 \mathrm{~mm}$ dan $>5 \mathrm{~mm}(\mathrm{p}=0,78)$. SFR berdasarkan variable lokasi batu adalah 67,1\%, 75,8\% dan 81,8\% masing-masing untuk batu residual dengan lokasi di pole atas, tengah, dan bawah. Tidak terdapat perbedaan yang signifikan pada ketiga variabel tersebut. Simpulan dari penelitian ini adalah ESWL dapat dijadikan sebagai sebuah prosedur tatalaksana tambahan yang efektif untuk mengatasi batu residual pasca PCNL dengan angka SFR yang memuaskan.

Kata kunci: Batu residual; nefrolitotomi perkutan; extracorporeal shock wave lithotripsi

Correspondence: Doddy M Soebadi, Department of Urology, Faculty of Medicine, Universitas Airlangga, Dr. Soetomo General Hospital. Jalan Mayjen Prof. Dr. Moestopo 6-8 Surabaya 60286 Indonesia. Phone: +62 31 5501318; Fax: +62 32 5024971. E-mail: dmsoebadi@gmail.com

pISSN:2355-8393 • eISSN: 2599-056x • doi: http://dx.doi.org/10.20473/fmi.v56i2.21231

- Fol Med Indones. 2020;56:127-130 • Received 12 Jan 2019 • Accepted 27 Jun 2019

- Open access under CC-BY-NC-SA license • Available at https://e-journal.unair.ac.id/FMI/ 


\section{INTRODUCTION}

Percutaneous nephrolithotomy (PCNL) is an effective procedure which is being considered as the gold standard in the treatment of large/complex renal calculi. The assessment of stone clearance after PCNL is based on the endoscopic appearance of the collecting system at the completion of the procedure. The average stonefree rate (SFR) after PCNL is between 74\%-83\% (Desai et al 2011, Rosette et al 2011). Reasons for failure of complete clearance during PCNL include poor visualization secondary to bleeding, inability to access a fragment containing calyx, and the subjective impression of prolonged operative time (Rosette et al 2011). Improper selection of the surgical technique as well as anatomic abnormalities, stone composition, and technical constraints may influence the number and size of residual stone.

Management of residual stone is important to prevent any morbidities in patients after the procedure. Residual stones after PCNL can cause several events such as recurrent stone growth and renal colic due to residual stone obstruction. In order to prevent this event or to maximize the SFR, additional procedures after PCNL are mandatory.

Several treatment options have been proposed for management of residual stone after PCNL, such as extracorporeal shockwave lithotripsy (ESWL), flexible ureteroscopy and re-PCNL (Olvera-Posada et al 2016). Among them, ESWL remains the least invasive procedure. However, the effectiveness of ESWL for residual fragment after PCNL itself is based on various factors, such as stone size, location and stone composition. Because of that, in this study we will evaluate the efficacy of ESWL in managing residual stones after PCNL based on those factors.

\section{MATERIALS AND METHODS}

This study used cross-sectional analytic design. The study was performed in Dr Soetomo General Hospital Surabaya. The data were taken from January 2012 to December 2016. The inclusion criteria was the presence of residual stones after PCNL. All patients with residual stones were treated with ESWL as an auxiliary procedure. Exclusion criteria were patients with multiple stone, or with history of underwent the other management for residual stone (such as nephroscopy, flexible ureterorenoscopy, medical therapy or ESWL before). All patients were evaluated preoperatively with plain x-rays of the kidneys, ureters, and bladder (KUB) and USG. Post-treatment follow-up with KUB and USG were used to monitor the fragmentation and clearance of stones. Data were analyzed descriptively and analytically with correlation using Chi-Square test with SPSS 21.

\section{RESULTS}

Our retrospective identified 125 eligible patients, including 71 males $(56.8 \%)$ and 54 females $(43.2 \%)$. Most samples were in age range of 51-60 years (39.2\%). Stone size $=5 \mathrm{~mm}$ was found on $38(30.4 \%)$ samples and stone size > $5 \mathrm{~mm}$ was found on $87(69.6 \%)$ samples. Location of stone; upper, middle and lower were $39(31.2 \%), 32(25.6 \%)$ and $54(43.2 \%)$, respectively. For composition of stone; calcium stone was found on $70(56 \%)$, mixed $33(26.4 \%)$ and noncalcium on $22(17.6 \%)$. The overall SFR was $72 \%$. (Table. 1)

Table 1. Characteristics of samples

\begin{tabular}{lcc}
\hline \multicolumn{1}{c}{ Variables } & $\mathrm{n}$ & $\%$ \\
\hline Sex & & \\
Male & 71 & 56.8 \\
Female & 54 & 43.2 \\
Age Interval (years) & & \\
$11-20$ & 2 & 1.6 \\
$21-30$ & 3 & 2.4 \\
$31-40$ & 18 & 14.4 \\
$41-50$ & 37 & 29.6 \\
$51-60$ & 49 & 39.2 \\
$61-70$ & 15 & 12.0 \\
$71-80$ & 1 & .8 \\
Stone Size & & \\
$\leq 5$ mm & 38 & 30.4 \\
$>5$ mm & 87 & 69.6 \\
Stone Location & & \\
Upper & 39 & 31.2 \\
Middle & 32 & 25.6 \\
Lower & 54 & 43.2 \\
Composition & & \\
Calcium & 70 & 56.0 \\
Mixed & 33 & 26.4 \\
Non-Calcium & 22 & 17.6 \\
Stone Clearance & & \\
Clear & 90 & 72.0 \\
Not Clear & 35 & 28.0 \\
\hline
\end{tabular}

Table 2 shows statistical analyses between SFR with stone size variable. stone location and stone composition using Chi Square test. There were no statistically significant difference between SFR in stone size variable, stone location and stone composition ( $\mathrm{p}$-values $=0.78 ; 0.35 ; 0.35$ ). 
Table 2. Correlation between variables with stone clearance

\begin{tabular}{|c|c|c|c|}
\hline \multirow{2}{*}{ Variables } & \multicolumn{2}{|c|}{ Stone Clearance } & \multirow{2}{*}{$\mathrm{p}$-value } \\
\hline & Clear n (\%) & Not Clear n (\%) & \\
\hline \multicolumn{4}{|l|}{ Stone Size } \\
\hline$\leq 5 \mathrm{~mm}$ & $28(73.7)$ & $10(26.3)$ & 0.78 \\
\hline$>5 \mathrm{~mm}$ & $62(71.3)$ & $25(28.7)$ & \\
\hline \multicolumn{4}{|l|}{ Stone Location } \\
\hline Upper & $25(64.1)$ & $14(35.9)$ & 0.35 \\
\hline Middle & $23(71.9)$ & $9(28.1)$ & \\
\hline Lower & $42(77.8)$ & $12(22.2)$ & \\
\hline \multicolumn{4}{|l|}{ Composition } \\
\hline Calcium & 47 (67.1) & $23(32.9)$ & 0.35 \\
\hline Mixed & $25(75.8)$ & $8(24.2)$ & \\
\hline Non-Calcium & $18(81.8)$ & $4(18.2)$ & \\
\hline
\end{tabular}

\section{DISCUSSION}

Urinary stone management has evolved over the last 30 years. Minimally invasive techniques can now be performed for urinary stones in almost all situations. Currently, several modalities have been studied to treat residual stones after PCNL. One of them is second-look flexible nephroscopy, which has a SFR up to 97\%. But, nephroscopy is an invasive modality and cannot be done on tubeless PCNL. Other modalities, such as RIRS, has SFR of $81.7 \%-91.3 \%$ after 3 months postoperatively (Hamamoto et al 2014, Xu et al 2012). However, just like nephroscopy, RIRS is an invasive procedure that requires a surgery preparation, operating room, anesthesia and postoperative care, therefore the cost-benefit ratio between these two modalities remains unclear.

Among the therapeutic modalities for treating residual stones after PCNL, only ESWL is a non-invasive procedure. ESWL shows many potential advantages over other procedures because it provides an anesthesia free, technically less demanding, and effective therapeutic modality with a low rate of complications (Pearle et al 2008).

Our study has some important findings. We demonstrated that ESWL have overall $72 \%$ SFR for residual stone after PCNL. If we did the subgroup analysis based on stone size, location and stone composition, the SFR of ESWL will varies from $64.1 \%$ 81.8\%. Study by Aminsharifi (2018) state that SFR of ESWL on residual stone post PCNL was also varied from $66.6 \%$ until $91.7 \%$. The highest SFR was achieved on stone that located on renal pelvis. This SFR differences may be due to differences in modalities that used to identify the residual stones after PCNL. In this study, we only used USG and KUB, whereas in the Aminsharifi et al's (2018) study, they used unenhanced CT scans. Several studies have shown that unenhanced
CT scans are superior to USG and KUB in detecting residual stones with a sensitivity up to $100 \%$ (Lee et al., 2015; Opondo et al., 2014; Zhang et al., 2009). This is our study limitation. However, our study also has advantages compared to Aminsharifi (2018) study. In their study, they did not examine the stone composition which might be a variable that affected the outcome, although in our study stone composition did not have significant differences. For further research, we advise that it might be better to analyzed stone composition and categorized into more specific group for example calcium oxalate stone group, tricalcium phosphate, magnesium ammonium phos-phate, and cystine.

\section{CONCLUSION}

The results of our study suggest that extracorporeal shock wave lithotripsy is an effective auxiliary procedure for managing residual stones after PNL. This procedure is associated with a satisfactory stone-free rate.

\section{REFERENCES}

Aminsharifi A, Irani D, Amirzargar H (2018). Shock wave lithotripsy is more effective for residual fragments after percutaneous nephrolithotomy than for primary stones of the same size: a matched pair cohort study. Current Urology 12, 27-32

Desai M, De Lisa A, Turna B, Rioja J, Walfridsson H, Addessi A, Wong C (2011). The clinical research office of the endourological society percutaneous nephrolithotomy global study: Staghorn versus nonstaghorn stones. International Braz J Urol, 37, 661

Hamamoto S, Yasui T, Okada A, Taguchi K, Kawai N, Ando, R, et al (2014). Endoscopic combined intrarenal surgery for large calculi: simultaneous use of flexible 
ureteroscopy and mini-percutaneous nephrolithotomy overcomes the disadvantageous of percutaneous nephrolithotomy nonotherapy. Journal of Endourology 28, 28-33

Lee HY, Yang YH, Lee YL, Shen JT, Jang MY, Shih PMC, et al (2015). Noncontrast computed tomography factors that predict the renal stone outcome after shock wave lithotripsy. Clinical Imaging 39, 845-850

Olvera-Posada D, Ali SN, Dion M, Alenezi H, Denstedt JD, Razvi H (2016). Natural history of residual fragments after percutaneous nephrolithotomy: evaluation of factors in related to clinical events and intervention. Urology 97, 46-50

Opondo D, Gravas S, Joyce A, Pearle M, Matsuda T, Sun YH, et al (2014). Standardization of patient outcomes reporting in percutaneous nephrolithotomy. Journal of Endourology 28, 767-774

Pearle M, Lingeman J, Leveillee R, Kuo R, et al (2008). Prospective randomized trial comparing shock wave lithotripsy and ureteroscopy for lower pole caliceal calculi $1 \mathrm{~cm}$ or less. Journal of Urology 179, S69-S73

Rosette J de la, Assimos D, Desai M, Gutierrez J, Lingeman J, et al (2011). The clinical research office of the endourological society percutaneous nephrolithotomy global study: indications, complications, and outcomes in 5803 Patients. Journal of Endourology 25, 11-17

Xu G, Li X, He Y, He Z (2012). Staged single-tract minimally invasive percutaneous nephrolithotomy and flexible ureteroscopy in the treatment of staghorn stone in patients with solitary kidney. Urological Research 40, 745-749

Zhang L, Peng F, Yang L, Zhao X, Yang J, Zhang X (2009). Effect of extracorporeal shock-wave lithotripsy on residual stones after different methods of surgery (abstract). Zhong Nan Da Xue Xue Bao Yi Xue Ban 34, 634-637 